Article

\title{
Diversity and Utilization of Edible Plants and Macro-Fungi in Subtropical Guangdong Province, Southern China
}

\author{
Juyang Liao ${ }^{1,2}$, Linping Zhang ${ }^{3}$, Yan Liu ${ }^{2}$, Qiaoyun $\mathrm{Li}^{2}$, Danxia Chen ${ }^{2}$, Qiang Zhang ${ }^{4}$ and \\ Jianrong $\mathrm{Li}^{5, *}$ \\ 1 College of Forestry, Beijing Forestry University, Beijing10083, China; liaojuyang@163.com \\ 2 Hunan Forest Botanical Garden, Changsha 410116, China; ly446864594@163.com (Y.L.); \\ liqiaoyun99@163.com (Q.L.); cdx873898657@163.com (D.C.) \\ 3 Key Laboratory of State Forestry Administration on Forest Ecosystem Protection and Restoration of Poyang \\ Lake Watershed (JXAU), Nanchang 330045, China; zlping619@163.com \\ 4 Guangdong Institute of Applied Biological Resources, Guangzhou 510260, China; zhangqiang06@giabr.gd.cn \\ 5 South China Botanical Garden, Chinese Academy of Sciences, Guangzhou 510650, China \\ * Correspondence: lijianrong@scbg.ac.cn; Tel.: +86-20-3725-2692
}

Received: 17 September 2018; Accepted: 22 October 2018; Published: 25 October 2018

\begin{abstract}
Food supply from forests is a fundamental component of forest ecosystem services, but information relating to suitability for human consumption and sustainable utilization of non-timber forest products (NTFPs) in developing countries is lacking. To address this gap in knowledge, diverse datasets of edible plants and macro-fungi were obtained from field collections, historical publications, and community surveys across seven cities in Guangdong Province (GP), southern China. Seven edible parts and five food categories of plant species were classified according to usage and specific nutrient components. Edible plant species were also categorized into different seasons and life forms. Our results show that at least 100 plant species (with 64 plant species producing fruit) and 20 macro-fungi were commonly used as edible forest products in subtropical GP. There were 55 and 57 species providing edible parts in summer and autumn, respectively. Many edible plants had multiple uses. Tree and herbaceous species made up the majority of the total. Our study provides evidence that both edible plants and macro-fungi can enrich the food supply for residents in rural and urban areas by acting as supplemental resources. We therefore suggest that, in spite of the prevalence of imported foods due to modern infrastructure, edible NTFPs from subtropical forests might be leveraged to support the increasing demand for food in an era of rapid urbanization and global change.
\end{abstract}

Keywords: edible forest product; forest biology; macro-fungi; non-timber forest products (NTFPs); Pan-Pearl River Delta

\section{Introduction}

Forests and trees are principal components of terrestrial ecosystems, providing the earth with a vast array of socio-ecological benefits [1-3]. Among these benefits, forest biodiversity is a crucial dimension, important for valuing ecosystem services, and has been attracting growing attention from municipal authorities, research agencies, and the public. The diversity of edible plants and macro-fungi is a special category of forest biodiversity. From a global perspective, food security is a major concern and will remain a great challenge for the rest of the 21st century, since crop yields have fallen in many countries and regions due to insufficient investments, irregular climate, and intense disturbance from agroforestry [4-7]. Forests, including natural and urban forests, are highly valuable to world 
food security, annually providing livelihoods and food for over 300 million people [8-11]. Moreover, urban greenspaces contribute to and preserve a considerable proportion of terrestrial biodiversity [12]. Investigation and evaluation of edible species diversity from natural forests and urban green spaces can increase our understanding of the food supply required to meet the demands of a growing population. Furthermore, efforts to describe edible species diversity are of theoretical significance to understand diversity patterns of local food species, in addition to increasing citizens' awareness of biodiversity protection. Currently, edible fungi, wheat, rice, corn, sorghum, cassava, and potato are the top seven major food crops in the world $[9,13]$. Edible forest products from diverse ecosystems are important supplements for the global food supply. As the largest developing country in the world and a major economic entity, China has the largest population in Asia-more than 1.41 billion as of 2016-and has diverse forest types, including tropical, subtropical, and temperate zones. Therefore, enriching the food supply and achieving food security are important tasks for the international community, regional governments, and local authorities.

Food diversity from forests (i.e., edible plants and macro-fungi) is described in order to reveal a vital component of forest biodiversity in subtropical Guangdong Province (GP), southern China. The objectives of the present study were three fold: (1) to obtain a comprehensive species list of edible plants and macro-fungi commonly used in the region; (2) to explore general patterns of edible plants among different edible parts, categories, seasons, and life forms; and (3) to evaluate the utilization and conservation of edible forest products. Overall, exploring the diversity of edible forest products adds to our understanding of the socio-ecological benefits of forests. These efforts assess the suitability of non-timber forest products (NTFPs) for human consumption, as well as the necessity and feasibility of green infrastructure construction in urbanizing regions.

\section{Materials and Methods}

\subsection{Research Area}

Guangdong Province $\left(20^{\circ} 09^{\prime}-25^{\circ} 31^{\prime} \mathrm{N}, 109^{\circ} 45^{\prime}-117^{\circ} 20^{\prime} \mathrm{E}\right)$ is located in southern China (Figure 1), geographically adjacent to Hong Kong SAR, Macao SAR, and 4 other provinces. GP consists of 21 prefecture-level cities and covers an area of $179,700 \mathrm{~km}^{2}$, with urbanized areas in the southeast and relatively rural areas in northwest. The typical vegetation is subtropical evergreen broadleaved forest, with natural habitats mainly distributed in the northwest, while there is a large proportion of urban forests and green spaces in the southeast. GP has a massive pool of forest resources, estimated to exceed 7400 vascular plant species and 1100 known macro-fungi [14,15]. Several major socioeconomic indicators were retrieved from the Guangdong Statistical Yearbook (2003-2016) (http:/ / www.gdstats. gov.cn/) (Table 1). As a highly urbanized region and major municipality in southern China, GP is representative of China's modernization process and forest biodiversity patterns. According to the official statistics, as of 2016 GP hosted 110 million residents and thus requires a large amount of imported food. 


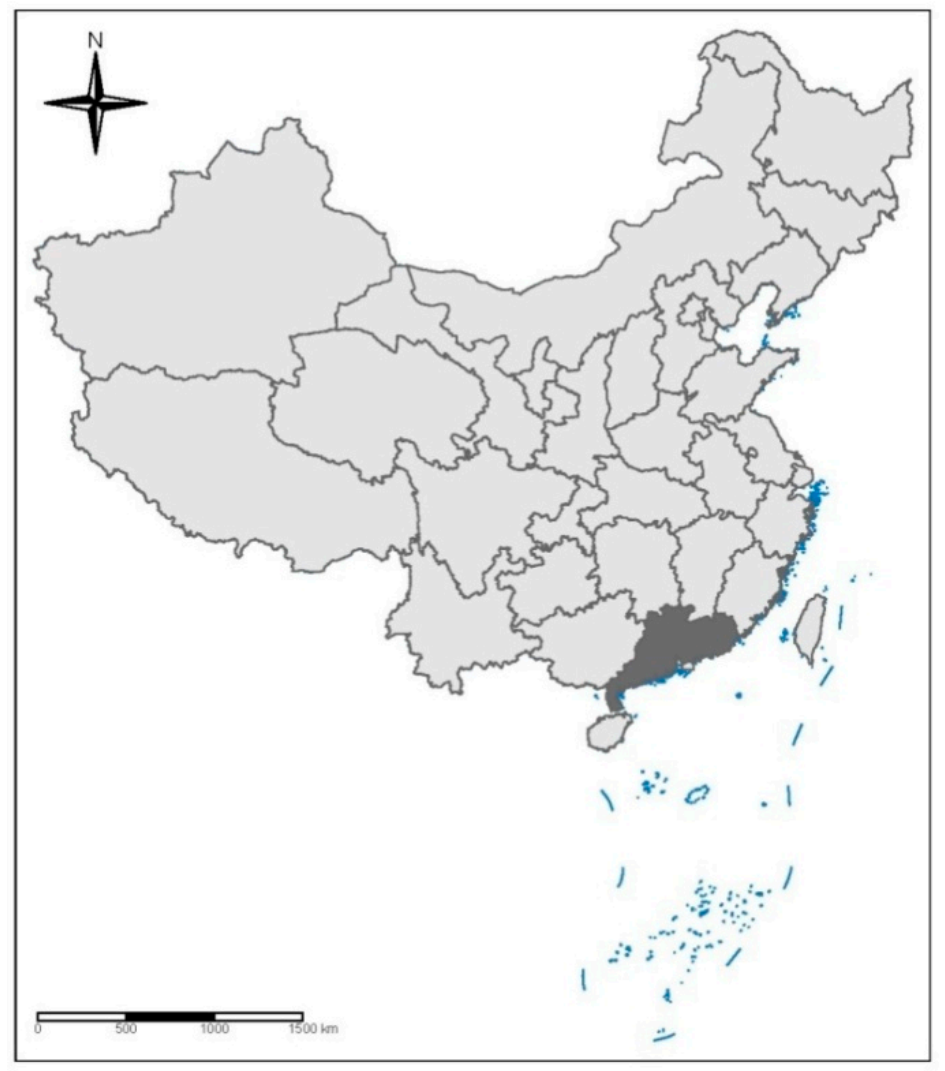

Figure 1. Location of Guangdong Province, southern China (highlighted in black).

\subsection{Edible Species Diversity and Taxonomic Information}

Records of edible species diversity (plants and fungi) and their illustrations were obtained from field observations and historical publications focusing on provincial forests (mostly natural reserves and forest parks), accompanied by community surveys at fruit stores and supermarkets. Sampling sites occurred in 4 cities (Foshan, Guangzhou, Shenzhen, and Zhongshan) located in highly urbanized areas of GP, and another 3 cities (Shaoguan, Zhanjiang, and Zhaoqing) located in relatively rural areas. Taxonomic information on all plant species (Supplementary Materials) refer to the English revision of Flora of China (http:/ / foc.eflora.cn/). Specifically, species name, family name, lifestyle, life form, and harvest time were collected. The names of fungi and their taxonomy are from Mycobank (http://www.mycobank.org/).

Each edible plant species was classified into 1 of the following 7 categories: root (tuber), stalk (bark, and/or shoot), leaf, flower, fruit, seed, and/or whole plant. For fungi, the whole sporocarp was considered an edible part; these are usually used as vegetables and medicinal supplements. Four seasons of food harvest were classified according the climatic conditions in Guangdong Province as follows: March to May, spring; June to August, summer; September to November, autumn; and December to February of the second year, winter. Five food types were included in this study according to their specific nutrient components: cereals and saccharides (providing carbohydrate and starch), fruits (including all fruit types, providing vitamins and protein), vegetables (providing vitamins), oil plants (including oil crops and products, providing vegetable fat), medicinal plants (providing primary healthcare), and spice plants (providing flavoring agents). Field surveys and sampling methods were conducted according to the "Observation Methodology for Long-term Forest Ecosystem Research" of the National Standards of the People's Republic of China (GB/T 33027-2016). All figures were produced using Adobe Photoshop CC 2015 (Adobe Systems Inc, San Jose, CA, USA). Statistical difference (one-sample test) was performed using SPSS (Standard version 13.0; SPSS, Chicago, IL, USA) among the 6 edible parts, 4 seasons, 5 categories, and 4 life forms. 
Table 1. General statistics of edible plants in Guangdong Province (2003-2016).

\begin{tabular}{|c|c|c|c|c|c|c|c|c|c|c|c|c|}
\hline \multirow{2}{*}{ Year } & \multirow{2}{*}{$\begin{array}{l}\text { Provincial GDP } \\
\text { (Billion CYN) }\end{array}$} & \multirow{2}{*}{$\begin{array}{l}\text { Primary Industry } \\
\text { (Billion CYN) }\end{array}$} & \multirow{2}{*}{$\begin{array}{l}\text { Proportion of Primary } \\
\text { Industry (\%) }\end{array}$} & \multicolumn{6}{|c|}{ Components of Edible Plants } & \multirow{2}{*}{$\begin{array}{l}\text { Population } \\
\text { (Million) }\end{array}$} & \multirow{2}{*}{$\begin{array}{l}\text { Proportion of Urban } \\
\text { Population (\%) }\end{array}$} & \multirow{2}{*}{$\begin{array}{c}\text { Forest } \\
\text { Coverage (\%) }\end{array}$} \\
\hline & & & & $\begin{array}{l}\text { Cereals } \\
\left(10^{9} \mathrm{~kg}\right) \\
\end{array}$ & $\begin{array}{l}\text { Saccharides } \\
\left(10^{9} \mathrm{~kg}\right)\end{array}$ & $\begin{array}{c}\text { Oils } \\
\left(10^{9} \mathrm{~kg}\right)\end{array}$ & $\begin{array}{l}\text { Vegetables } \\
\left(10^{9} \mathrm{~kg}\right)\end{array}$ & $\begin{array}{c}\text { Fruits } \\
\left(10^{9} \mathrm{~kg}\right)\end{array}$ & $\begin{array}{c}\text { Tea } \\
\left(10^{6} \mathrm{~kg}\right)\end{array}$ & & & \\
\hline 2003 & 1344.99 & 105.16 & 7.82 & 14.88 & 9.53 & 0.82 & 25.84 & 7.19 & 41.40 & 79.54 & NA & 57.3 \\
\hline 2004 & 1603.95 & 124.54 & 7.76 & 13.90 & 9.41 & 0.78 & 25.58 & 7.88 & 40.40 & 83.04 & NA & 57.40 \\
\hline 2005 & 2170.13 & 137.46 & 6.33 & 13.95 & 9.46 & 0.77 & 25.96 & 8.32 & 44.50 & 91.94 & NA & 57.50 \\
\hline 2006 & 2596.86 & 157.14 & 6.05 & 13.88 & 11.24 & 0.78 & 26.44 & 8.93 & 47.40 & 93.04 & 63.00 & NA \\
\hline 2007 & 3067.37 & 174.62 & 5.69 & 12.85 & 10.56 & 0.79 & 26.54 & 9.51 & 48.90 & 94.49 & 63.10 & 56.00 \\
\hline 2008 & 3569.65 & 197.02 & 5.52 & 12.43 & 10.79 & 0.82 & 24.31 & 9.83 & 48.40 & 95.44 & 63.40 & 56.30 \\
\hline 2009 & 3908.16 & 200.60 & 5.13 & 13.14 & 11.16 & 0.85 & 25.67 & 10.62 & 51.40 & 96.38 & 63.40 & 56.70 \\
\hline 2010 & 4547.28 & 228.69 & 5.03 & 13.17 & 11.34 & 0.88 & 27.21 & 11.29 & 52.60 & NA & NA & 57.00 \\
\hline 2011 & 5267.36 & 265.98 & 5.05 & 13.61 & 12.03 & 0.92 & 28.60 & 12.10 & 58.10 & 105.05 & 66.50 & 57.30 \\
\hline 2012 & 5706.79 & 284.89 & 4.99 & 13.96 & 12.79 & 0.97 & 29.83 & 12.79 & 63.10 & 105.94 & 67.40 & 57.70 \\
\hline 2013 & 6216.40 & 304.75 & 4.90 & 13.16 & 13.59 & 1.01 & 31.44 & 13.69 & 69.80 & 106.44 & 67.76 & 58.20 \\
\hline 2014 & 6779.22 & 316.67 & 4.67 & 13.57 & 13.08 & 1.05 & 32.75 & 14.36 & 73.90 & 107.24 & 68.00 & 58.70 \\
\hline 2015 & 7281.26 & 334.48 & 4.59 & 13.58 & 12.51 & 1.10 & 34.39 & 15.21 & 79.30 & 108.49 & 68.71 & 58.88 \\
\hline 2016 & 7951.20 & 369.36 & 4.64 & 13.60 & 12.70 & 1.13 & 35.80 & 15.80 & 85.00 & 109.99 & 69.20 & 58.98 \\
\hline
\end{tabular}




\section{Results}

\subsection{Major Crops in Guangdong Province}

In recent years, social and economic growth has increased in Guangdong Province (Table 1). Provincial gross domestic product (GDP) and primary industry increased by 490\% and 250\% from 2003 to 2016, respectively. Primary industry accounted for a relatively low and stable proportion of GDP in GP, ranging from $4.59 \%$ in 2015 to $7.82 \%$ in 2003 . The permanent resident population increased by $38 \%$ (30.45 million), whereas the proportion of urban population increased by $6 \%$, to nearly $70 \%$, from 2006 to 2016. Cereals decreased by 8\% from 2003 to 2016, although yield remained relatively stable. Saccharides, oils, and vegetables all increased by one-third. Fruits increased by $120 \%$; interestingly, the famous local lychee fruit tree (Litchi chinensis Sonn.) contributed slightly over $10 \%$ of the total fruit yield.

\subsection{Patterns of Species Diversity and Edible Parts}

Species diversity of edible plants was found to be relatively high in the study region. As many as 100 plant species (including var. and cv.) belonging to 88 genera in 51 families were identified (Supplementary Materials). Interestingly, 37\% of edible plants were from several common families: nine species from Rosaceae; six species from Fabaceae, Myrtaceae, and Rutaceae; and five species from Poaceae. Species producing fruit parts contributed $>60 \%$ of the total species, and some plants had multiple edible parts. Specifically, 64 species were identified with edible fresh or dried fruits, 11 species with edible roots or tubers, 10 species with edible seeds, 7 species with edible leaves, 6 species with edible flowers or whole plant, and 3 species with edible bark, stalks, or shoots. Statistical difference was not significant $(\mathrm{t}=1.771$, $\mathrm{df}$ (degree of freedom) $=5, p=0.137 ; \mathrm{t}=2.402, p=0.061$ when six species with edible whole plant were accumulated to each part accordingly) among the six edible parts (Figure 2A).

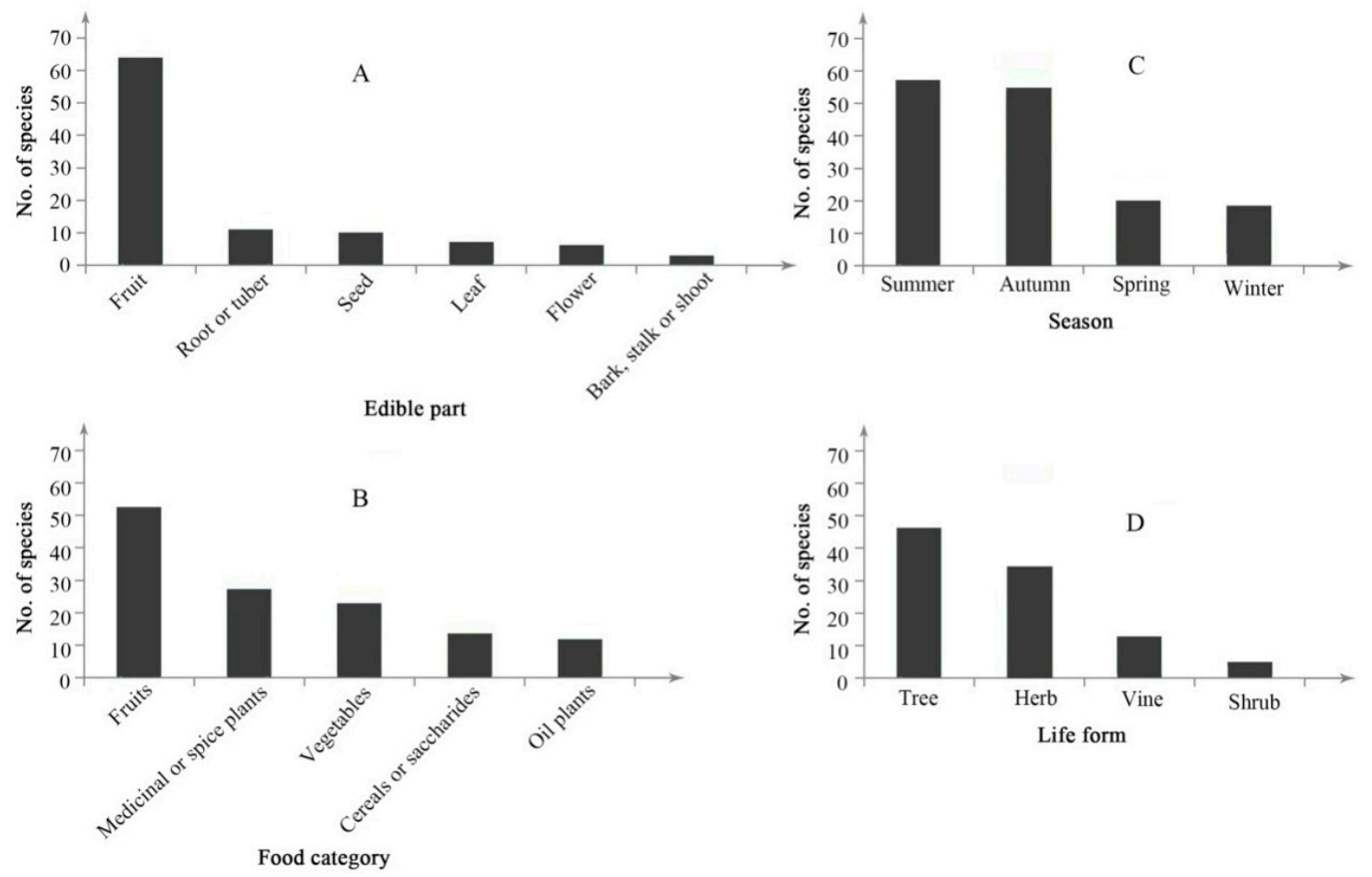

Figure 2. Categories of edible plant species commonly found in Guangdong Province, southern China: (A) edible parts; (B) food categories; (C) seasonal patterns; and (D) life forms. 


\subsection{Seasonal Patterns and Food Categories of Edible Forest Products}

Over half of the total plant species provided edible parts in the summer and autumn, with some plants spanning multiple seasons (Supplementary Materials). Specifically, 57 species were available in autumn, 55 species in summer, 20 species in spring, and 18 species in winter. Furthermore, eight species were available across all four seasons. Statistical difference was significant $(t=3.506, d f=3$, $p=0.039 ; \mathrm{t}=4.254, p=0.024$ when eight species available during the full year were accumulated to each season accordingly) among the four seasons (Figure 2C). Many edible plants had multiple uses. Specifically, 53 species were used as fruits, 27 species as medicinal or spice plants, 23 species as vegetables, 14 species as cereals or saccharides, and 12 species as oil plants. Statistical difference was significant $(\mathrm{t}=3.513, \mathrm{df}=4, p=0.025)$ among the five categories (Figure $2 \mathrm{~B}$ ). Tree and herbaceous species made up approximately half and one-third of the total, respectively, while shrub species accounted for only $5 \%$ of the total. Statistical difference was not significant $(\mathrm{t}=2.579, \mathrm{df}=3, p=0.082)$ among the four life forms (Figure 2D).

Furthermore, 20 common edible macro-fungi were recorded, belonging to 16 families (Supplementary Materials). Three out the 20 species were from the family Pleurotaceae. The majority of fungus species were cultivated, accompanied by some wild species found in forests. For instance, wild species Boletus speciosus Frost and Russula vinosa Lindblad usually appeared in the summer and autumn. The whole sporocarp was edible, mostly used as a vegetable. Moreover, about two-thirds of the species pool could be used as medicinal supplements.

\section{Discussion}

The benefits of forest ecosystems are extremely diverse. The composition of food consumption, from the global perspective, is trending toward better, healthier, and more diverse foods $[4,7,16,17]$. Edible plants and macro-fungi are important because they provide livelihoods for people $[11,18,19]$. A growing number of Chinese people pursue a high-quality lifestyle (e.g., realizing the importance of a vegetarian diet) [16,20]. The reported 100 edible plants and 20 macro-fungi were identified based on a preliminary investigation within Guangdong Province, southern China. Particularly, biodiversity conservation and food supply in the region were investigated in order to understand how they might address poverty alleviation and sustainable utilization, which are increasingly important due to global changes and rapid urbanization. Our findings might also be utilized by local authorities and stakeholders adjacent to GP (such as Hunan and Jiangxi Provinces and the Pan-Pearl River Delta).

\subsection{Biodiversity Conservation of Forest Resources}

Species diversity is the basis of biodiversity conservation. High species diversity can help counteract homogeneous food resources in the region $[6,13,21]$. In light of the more than 7400 woody species and 300 macro-fungi already described in GP, additional species are likely to be edible $[15,22]$. In particular, the presence of endemic species (e.g., fruit species Dimocarpus longan Lour., Litchi chinensis Sonn., and Mangifera indica L.; vegetable species Hylocereus undatus Haw., Lycium chinense Mill. var. chinense, and Sechium edule (Jacq.) Swartz; and medicine species Ficus hirta Vahl., Archidendron clypearia Jack., and Plumeria rubra L.) demonstrates the value of preserving regional biodiversity. Genetic diversity serves as another important component of biodiversity. High genetic diversity is important to maintain phylogenetic community structure [23-26]. Interestingly, numerous studies have reported that hidden/cryptic genetic biodiversity can be revealed through modern taxonomic methods such as DNA barcoding $[27,28]$. Our results show that there is a moderate proportion of wild plants (14\% wild, i.e., the species seldom exists in the form of a cultivar; and another $23 \%$ partially wild, i.e., the species has the potential to be domesticated) (Supplementary Materials), which suggests that the genetic diversity of edible plants needs to be improved, and may function as a reservoir of biodiversity in the region. In terms of landscape diversity, the third component of biodiversity, the present study provides very little information. However, we agree with previous 
findings that actions and policies that protect living habitats and landscape components for wild plants, animals, and fungi are vital to regional biodiversity conservation in natural forests and urban green spaces [29,30].

Forests provide humans with multiple benefits, from subsistence to safety nets and cash income. In most cases, however, trade-offs may exist between exploitation and protection of forest resources. People could largely depend on local forest products, but deforestation and overexploitation might prevail in the absence of adequate protection, especially in face of strong global demand [31,32]. We suggest that one way to protect forest-based livelihoods while avoiding overexploitation would be to use an alternative solution that synergizes social and ecological benefits [33-35], with goals for sustainable forestry practices and win-win solutions. Future efforts might include the regions adjacent to GP, such as Hunan and Jiangxi Provinces, which geographically share the Nanling Mountains, a global biodiversity hotspot [36,37].

\subsection{Food Supply in Different Seasons}

Urban landscapes (e.g., ground-level and green rooftop gardens) have the potential to produce a large proportion of food crops (e.g., fresh fruits and vegetables) for a dense population, developing a local urban food system and providing eco-environmental benefits [38-40]. Due to the rapid socioeconomic development in China, attributed to the reform and opening-up policy (since 1978) and entry into the World Trade Organization (WTO) (since 2001), the dietary structure of residents has dramatically changed in GP with the availability of a diverse food supply throughout the year. It is now easy to obtain fresh fruits and vegetables via novel technologies like soilless culture, greenhouse cropping, and convenient transportation. However, we should also respect the natural life cycle of plants. Our results show that only a small proportion $(\sim 20 \%)$ of edible plant species were available in GP in the winter (such as Chrysanthemum morifolium cv. Hangju, Garcinia mangostana L., Manihot esculenta Crantz, Trachycarpus fortune (Hook.) H. Wendl, Puerariamontana var. thomsonii (Willd.), etc.) or spring (such as Ananascomosus L., Bombax ceiba L., Houttuynia cordata Thunb., etc.), though without specific everyday consumption, similar to previous studies calling for sustainable agroforestry and uninterrupted supplies of edible crops [9,19,41,42].

Edible forest products could be treated as an alternative defense against crises that affect food supply. Cereals are the most important food type supporting the current and projected global human population [43]. However, the yield of cereals largely depends on nutrient investments, climate change, and human activities, which might result in an imbalance of food supply at a particular time or place [44]. Our results show that there is tremendous potential for fruit trees, garden vegetables, and edible macro-fungi from nature to supplement the human food supply in the future. These edible forest products, though they are inflexible and sometimes have low returns, may still ensure sustainable food security for communities and generate as much income as cultivating crops in the long term $[16,23,45]$.

\subsection{Estimation of Livelihoods from Forests}

Foods from forests and urban green spaces contribute a small proportion of everyday food consumption. In Guangdong Province, Flammulina velutipes (Curtis) Singer and Pleurotus ostreatus (Jacq.) P. Kumm. were the top two edible fungi, with a yield of $1.71 \times 10^{8} \mathrm{~kg}$ and $1.36 \times 10^{8} \mathrm{~kg}$, respectively, according to a public report released by the Edible Fungus Index (http://www. mushroommarket.net/datas/). Among the species pool of 100 edible plants in this study, at least one-third were wild or partially wild species, which are not yet domesticated and exploited as are other major cultivars (e.g., lychee). Compared to the high regional species diversity, the proportions of edible plant diversity $(\sim 1.35 \% ; 100 / 7400)$ and known macro-fungi $(\sim 1.82 \% ; 20 / 1100)$ were relatively low [46], which indicates that wild plant and fungus resources were not overexploited and in situ conservation generally works well in GP. Meanwhile, many more wild species are likely to be edible and are expected to enrich the species diversity of forest food in this region. However, it should be 
noted that many wild plants and fungi are poisonous (sometimes fatal) if eaten by mistake, which calls for the involvement of knowledgeable professionals.

Currently, poverty remains an important problem for over 1.2 billion people, mostly in developing countries and especially in rural areas $[9,11,18,47]$. Three principal ideas may achieve forest-based poverty alleviation: prevent forest resources from shrinking, if they are necessary to maintain well-being (protect the pie); make forests accessible and redistribute resources and rents (divide the pie differently); and increase the value of forest production (enlarge the pie) [48]. It is estimated that the livelihoods of $\sim 20 \%$ of the global population are supported by forest products, serving as subsistence, safety nets, and pathways to prosperity [11]. Environmental income (e.g., transfer of ownership of natural forests and other urban green spaces to local communities, coupled with payments for improved ecosystem services) accounts for one-third of total household income [18,49]. In addition to plants and macro-fungi, animal proteins provided by wildlife and insects could benefit human nutrition and provide special livelihoods in some rural areas $[17,50,51]$.

\section{Conclusions}

This study reports state-of-the-art knowledge on common forest products (i.e., edible plants and macro-fungi) in lower subtropical forests in southern China. Efforts to protect natural forests and urban green spaces should continue in order to prevent biodiversity loss. Domestication of edible wild plants could be reinforced to enrich livelihoods for highly urbanized regions. Exploration of more edible plants, macro-fungi, and insects might be expected to add to the food supply. We show that endeavors to explore the diversity of edible forest products could strengthen our understanding of the socio-ecological benefits of subtropical forests.

Supplementary Materials: The following are available online at http:/ /www.mdpi.com/1999-4907/9/11/666/ s1.

Author Contributions: J.L. (Jianrong Li), J.L. (Juyang Liao) and L.Z. conceived the idea, compiled the datasets, and conducted analyses. J.L. (Juyang Liao), L.Z., Y.L., Q.L., Q.Z., and J.L. (Jianrong Li) established the direction. J.L. (Juyang Liao) and J.L. (Jianrong Li) wrote the first draft of the manuscript. J.L. (Juyang Liao), L.Z., Y.L., Q.L., D.C., Q.Z., and J.L. (Jianrong Li) contributed with suggestions and corrections, and approved the final manuscript.

Funding: This study was funded by the Fundamental Research Funds of CAF (CAFYBB2017QB002), Science and Technology Key R \& D Program of Hunan Province (2017SK2332), National Natural Science Foundation of China (31660189), Pearl River S\&T Nova Program of Guangzhou (201610010001), and CFERN \& BEIJING TECHNO SOLUTIONS Award Funds on excellent academic achievements.

Acknowledgments: We are grateful to three anonymous reviewers for valuable ideas and/or comments on the manuscript.

Conflicts of Interest: The authors declare no conflict of interest.

\section{References}

1. Boyd, I.L.; Freer-Smith, P.H.; Gilligan, C.A.; Godfray, H.C.J. The Consequence of Tree Pests and Diseases for Ecosystem Services. Science 2013, 342, 1235773. [CrossRef] [PubMed]

2. Nowak, D.J.; Crane, D.E.; Stevens, J.C.; Hoehn, R.E.; Walton, J.T.; Bond, J. A ground-based method of assessing urban forest structure and ecosystem services. Arboricult. Urban For. 2008, 34, 347-358.

3. Costanza, R.; de Groot, R.; Sutton, P.; van der Ploeg, S.; Anderson, S.J.; Kubiszewski, I.; Farber, S.; Turner, R.K. Changes in the global value of ecosystem services. Glob. Environ. Chang. 2014, 26, 152-158. [CrossRef]

4. Poleman, T.T. World Food: A Perspective. Science 1975, 188, 510-518. [CrossRef] [PubMed]

5. Schmidhuber, J.; Tubiello, F.N. Global food security under climate change. Proc. Natl. Acad. Sci. USA 2007, 104, 19703-19708. [CrossRef] [PubMed]

6. Campbell, B.M.; Vermeulen, S.J.; Aggarwal, P.K.; Corner-Dolloff, C.; Girvetz, E.; Loboguerrero, A.M.; Ramirez-Villegas, J.; Rosenstock, T.; Sebastian, L.; Thornton, P.K.; et al. Reducing risks to food security from climate change. Glob. Food Secur. 2016, 11, 34-43. [CrossRef]

7. Vermeulen, S.J.; Campbell, B.M.; Ingram, J.S.I. Climate Change and Food Systems. Annu. Rev. Environ. Resour. 2012, 37, 195-222. [CrossRef] 
8. Pimentel, D.; McNair, M.; Buck, L.; Pimentel, M.; Kamil, J. The Value of Forests to World Food Security. Hum. Ecol. 1997, 25, 91-120. [CrossRef]

9. Alexandratos, N.; Bruinsma, J. World Agriculture towards 2030/2050: The 2012 Revision; Food and Agriculture Organization of the United Nations: Rome, Italy, 2012.

10. Rosegrant, M.W.; Cline, S.A. Global Food Security: Challenges and Policies. Science 2003, 302, $1917-1919$. [CrossRef] [PubMed]

11. Cheng, S.H.; Ahlroth, S.; Onder, S.; Shyamsundar, P.; Garside, R.; Kristjanson, P.; McKinnon, M.C.; Miller, D.C. What is the evidence for the contribution of forests to poverty alleviation? A systematic map protocol. Environ. Evid. 2017, 6, 10. [CrossRef]

12. MacGregor-Fors, I.; Escobar, F.; Rueda-Hernández, R.; Avendaño-Reyes, S.; Baena, M.; Bandala, V.; Chacón-Zapata, S.; Guillén-Servent, A.; González-García, F.; Lorea-Hernández, F.; et al. City “Green” Contributions: The Role of Urban Greenspaces as Reservoirs for Biodiversity. Forests 2016, 7, 146. [CrossRef]

13. Pimentel, D.; Wilson, C.; McCullum, C.; Huang, R.; Dwen, P.; Flack, J.; Tran, Q.; Saltman, T.; Cliff, B. Economic and Environmental Benefits of Biodiversity. BioScience 1997, 47, 747-757. [CrossRef]

14. Song, B.; Zhong, Y.; Deng, W.; Shen, Y.; Li, J.; Lin, M. Resouces of wild macrofungi and prospects of their exploitation in Guangdong China. J. Microbiol. 2007, 27, 59-63. (In Chinese)

15. Ye, H.; Xing, F. Checklist of Guangdong Plants; World Publishing Guangdong Corporation: Guangzhou, China, 2005.

16. Fan, S.; Brzeska, J. Sustainable food security and nutrition: Demystifying conventional beliefs. Glob. Food Secur. 2016, 11, 11-16. [CrossRef]

17. Golden, C.D.; Fernald, L.C.H.; Brashares, J.S.; Rasolofoniaina, B.J.R.; Kremen, C. Benefits of wildlife consumption to child nutrition in a biodiversity hotspot. Proc. Natl. Acad. Sci. USA 2011, 108, 19653-19656. [CrossRef] [PubMed]

18. Angelsen, A.; Jagger, P.; Babigumira, R.; Belcher, B.; Hogarth, N.J.; Bauch, S.; Börner, J.; Smith-Hall, C.; Wunder, S. Environmental Income and Rural Livelihoods: A Global-Comparative Analysis. World Dev. 2014, 64, S12-S28. [CrossRef]

19. Russo, A.; Escobedo, F.J.; Cirella, G.T.; Zerbe, S. Edible green infrastructure: An approach and review of provisioning ecosystem services and disservices in urban environments. Agric. Ecosyst. Environ. 2017, 242, 53-66. [CrossRef]

20. Wang, Z.H.; Zhai, F.Y.; Du, S.F.; Popkin, B. Dynamic shifts in Chinese eating behaviors. Asia Pac. J. Clin. Nutr. 2008, 17, 123-130. [PubMed]

21. Kirkpatrick, J.B.; Davison, A. Home-grown: Gardens, practices and motivations in urban domestic vegetable production. Landsc. Urban Plan. 2018, 170, 24-33. [CrossRef]

22. Zhou, L.; Yang, Z.; Wen, H.; Bau, T.; Li, T. A revised checklist of edible fungi in China. Mycosystema 2010, 29, 1-21. (In Chinese)

23. Charnley, S.; Poe, M.R. Community Forestry in Theory and Practice: Where Are We Now? Annu. Rev. Anthropol. 2007, 36, 301-336. [CrossRef]

24. Pereira, H.M. A latitudinal gradient for genetic diversity. Science 2016, 353, 1494-1495. [CrossRef] [PubMed]

25. Harlan, J.R. Our Vanishing Genetic Resources. Science 1975, 188, 618-621. [CrossRef] [PubMed]

26. Swenson, N.G.; Erickson, D.L.; Mi, X.; Bourg, N.A.; Forero-Montana, J.; Ge, X.; Howe, R.; Lake, J.K.; Liu, X.; Ma, K.; et al. Phylogenetic and Functional Alpha and Beta Diversity in Temperate and Tropical Tree Communities. Ecology 2012, 93, S112-S125. [CrossRef]

27. Lahaye, R.; van der Bank, M.; Bogarin, D.; Warner, J.; Pupulin, F.; Gigot, G.; Maurin, O.; Duthoit, S.; Barraclough, T.G.; Savolainen, V. DNA barcoding the floras of biodiversity hotspots. Proc. Natl. Acad. Sci. USA 2008, 105, 2923-2928. [CrossRef] [PubMed]

28. Janzen, D.H.; Burns, J.M.; Cong, Q.; Hallwachs, W.; Dapkey, T.; Manjunath, R.; Hajibabaei, M.; Hebert, P.D.N.; Grishin, N.V. Nuclear genomes distinguish cryptic species suggested by their DNA barcodes and ecology. Proc. Natl. Acad. Sci. USA 2017, 114, 8313-8318. [CrossRef] [PubMed]

29. Ashley, R.; Russell, D.; Swallow, B. The Policy Terrain in Protected Area Landscapes: Challenges for Agroforestry in Integrated Landscape Conservation. Biodivers. Conserv. 2006, 15, 663-689. [CrossRef]

30. Livesley, S.J.; McPherson, E.G.; Calfapietra, C. The Urban Forest and Ecosystem Services: Impacts on Urban Water, Heat, and Pollution Cycles at the Tree, Street, and City Scale. J. Environ. Qual. 2016, 45, 119-124. [CrossRef] [PubMed] 
31. DeFries, R.S.; Rudel, T.; Uriarte, M.; Hansen, M. Deforestation driven by urban population growth and agricultural trade in the twenty-first century. Nat. Geosci. 2010, 3, 178. [CrossRef]

32. Edwards, D.P.; Magrach, A.; Woodcock, P.; Ji, Y.; Lim, N.T.L.; Edwards, F.A.; Larsen, T.H.; Hsu, W.W.; Benedick, S.; Khen, C.V.; et al. Selective-logging and oil palm: Multitaxon impacts, biodiversity indicators, and trade-offs for conservation planning. Ecol. Appl. 2014, 24, 2029-2049. [CrossRef] [PubMed]

33. Laurance, W.F.; Carolina Useche, D.; Rendeiro, J.; Kalka, M.; Bradshaw, C.J.A.; Sloan, S.P.; Laurance, S.G.; Campbell, M.; Abernethy, K.; Alvarez, P.; et al. Averting biodiversity collapse in tropical forest protected areas. Nature 2012, 489, 290-294. [CrossRef] [PubMed]

34. Lindenmayer, D.B.; Laurance, W.F. The ecology, distribution, conservation and management of large old trees. Biol. Rev. 2017, 92, 1434-1458. [CrossRef] [PubMed]

35. Persha, L.; Agrawal, A.; Chhatre, A. Social and Ecological Synergy: Local Rulemaking, Forest Livelihoods, and Biodiversity Conservation. Science 2011, 331, 1606-1608. [CrossRef] [PubMed]

36. Chen, Y.-S.; Deng, T.; Zhou, Z.; Sun, H. Is the East Asian flora ancient or not? Natl. Sci. Rev. 2018, in press. [CrossRef]

37. Myers, N.; Mittermeier, R.A.; Mittermeier, C.G.; Fonseca, G.A.B.D.; Kent, J. Biodiversity hotspots for conservation priorities. Nature 2000, 403, 853-858. [CrossRef] [PubMed]

38. Saha, M.; Eckelman, M.J. Growing fresh fruits and vegetables in an urban landscape: A geospatial assessment of ground level and rooftop urban agriculture potential in Boston, USA. Landsc. Urban Plan. 2017, 165, 130-141. [CrossRef]

39. Dieleman, H. Urban agriculture in Mexico City; balancing between ecological, economic, social and symbolic value. J. Clean. Prod. 2017, 163, S156-S163. [CrossRef]

40. Camps-Calvet, M.; Langemeyer, J.; Calvet-Mir, L.; Gómez-Baggethun, E. Ecosystem services provided by urban gardens in Barcelona, Spain: Insights for policy and planning. Environ. Sci. Policy 2016, 62, 14-23. [CrossRef]

41. Guarrera, P.M.; Savo, V. Wild food plants used in traditional vegetable mixtures in Italy. J. Ethnopharmacol. 2016, 185, 202-234. [CrossRef] [PubMed]

42. Lindenmayer, D.B.; Franklin, J.F.; Lõhmus, A.; Baker, S.C.; Bauhus, J.; Beese, W.; Brodie, A.; Kiehl, B.; Kouki, J.; Pastur, G.M.; et al. A major shift to the retention approach for forestry can help resolve some global forest sustainability issues. Conserv. Lett. 2012, 5, 421-431. [CrossRef]

43. Ladha, J.K.; Tirol-Padre, A.; Reddy, C.K.; Cassman, K.G.; Verma, S.; Powlson, D.S.; van Kessel, C.; de B. Richter, D.; Chakraborty, D.; Pathak, H. Global nitrogen budgets in cereals: A 50-year assessment for maize, rice, and wheat production systems. Sci. Rep. 2016, 6, 19355. [CrossRef] [PubMed]

44. Lyu, Y.; Tang, H.; Li, H.; Zhang, F.; Rengel, Z.; Whalley, W.R.; Shen, J. Major Crop Species Show Differential Balance between Root Morphological and Physiological Responses to Variable Phosphorus Supply. Front. Plant Sci. 2016, 7, 1939. [CrossRef] [PubMed]

45. Wunder, S.; Angelsen, A.; Belcher, B. Forests, Livelihoods, and Conservation: Broadening the Empirical Base. World Dev. 2014, 64, S1-S11. [CrossRef]

46. Zhang, W.; Li, T.; Song, B. A survey on the macrofungi in Guangdong province. Ecol. Sci. 2001, 20, 48-58.

47. Zhuo, L.; Wang, L.; Chen, Q.; Liu, W. Wild fruit resources and exploitation in Xiaoxing'an Mountains. J. For. Res. 1999, 10, 31-33.

48. Sunderlin, W.D.; Angelsen, A.; Wunder, S. Forests and poverty alleviation. In State of the World's Forests; Center for International Forestry Research: Bogor Barat, Indonesia, 2003; pp. 61-73.

49. Chhatre, A.; Agrawal, A. Trade-offs and synergies between carbon storage and livelihood benefits from forest commons. Proc. Natl. Acad. Sci. USA 2009, 106, 17667-17670. [CrossRef] [PubMed]

50. Yen, A.L. Edible insects: Traditional knowledge or western phobia? Entomol. Res. 2009, 39, $289-298$. [CrossRef]

51. Lee, T.M.; Sigouin, A.; Pinedo-Vasquez, M.; Nasi, R. The Harvest of Wildlife for Bushmeat and Traditional Medicine in East, South and Southeast Asia: Current Knowledge Base, Challenges, Opportunities and Areas for Future Research; CIFOR: Bogor, Indonesia, 2014; Volume 115.

(C) 2018 by the authors. Licensee MDPI, Basel, Switzerland. This article is an open access article distributed under the terms and conditions of the Creative Commons Attribution (CC BY) license (http:/ / creativecommons.org/licenses/by/4.0/). 